\title{
THE KNIFE CREEK GLACIERS OF KATMAI NATIONAL MONUMENT, ALASKA*
}

\author{
By ERnest H. Muller and Henry W. Coulter \\ (U.S. Geological Survey, Washington, D.C.)
}

\begin{abstract}
A group of previously unmapped glaciers on the slopes of Trident and Katmai Volcanoes, southwestern Alaska, was studied for information on the abnormal regimen produced by effects of the 1912 eruption of Mount Katmai. During the eruption an area of 5 square miles $\left(13 \mathrm{~km} . .^{2}\right)$ of the summit above regional snow line was destroyed, and the beheaded glaciers were buried under a blanket of pumice and ash. Field data are presented to indicate that the terminus of Fourth Glacier has been essentially stationary since the 1912 eruption. Upper portions of the glacier have thinned, exposing the rim of the caldera which 40 years ago was partly ringed with fringing ice cliffs. Permafrost has developed to within a few feet of the surface of the pumice mantle. Under prevailing climatic conditions Fourth Glacier may be preserved in its present static condition for an indefinite period.
\end{abstract}

Zusammenfassung. Eine Gletschergruppe an den Abhängen von Trident und Katmai Volcanoes, SüdwestAlaska, wurde untersucht, um Aufschluss über das durch Einwirkungen des im Jahre I 912 ausgebrochenen Mount Katmai annormale System zu erhalten. Während des Ausbruches wurde eine Fläche von $13 \mathrm{~km}^{2}$ am Gipfẹl über der regionalen Schneelinie zerstört, und die geköpften Gletscher wurden unter einer Decke von Bimstein und Asche begraben. Es werden Angaben auf der Stelle gemacht, um zu zeigen, dass das Ende des Fourth Glacier seit dem Ausbruch des Jahres I912 erforderlicherweise stationär geblieben ist. Obere Teile des Gletschers sind dünner geworden und haben dadurch den Rand des Kaldera enthüllt, der vor $40 \mathrm{~J}$ ahren teilweise von umsäumenden Eisklippen eingeschlossen war. Dauerfrost hat sich innerhalb weniger Meter der Oberfläche des Bimsteinmantels entwickelt. Unter den vorherrschenden klimatischen Bedingungen ist es möglich, dass der Fourth Glacier in seinem gegenwärtigen statischen Zustand für unbegrenzte Zeit enhalten bleibt.

\section{INTRODUCTION}

In July and September 1953, under joint sponsorship of the U.S. Geological Survey and the National Park Service, Katmai Project, the writers made limited glaciological observations in Katmai National Monument, south-western Alaska (Fig. I, p. I17) to investigate the unusual regimen of glaciers on the western slopes of Katmai and Trident Volcanoes. In 1912, during the violent eruption of Katmai Volcano, summit collapse beheaded several of these glaciers, and all were buried beneath tuff and pumice ejected from adjacent vents.

The glaciers within the boundaries of Katmai National Monument occur on slopes of the higher peaks of the Aleutian Range from the vicinity of Cape Douglas (Fig. I), in the north-eastern part of the Monument, to the Kejulik Mountains on the south border. The principal glacier concentrations are between Mount Douglas and Four-Peaked Mountain in the north-east and between Devils Desk and Martin Volcano in the east-central and southern sections. Of the glaciers in these areas, the majority are ash-free and appear normal in their regimen and dynamics, but a smaller number are covered by a layer of pumice thick enough to affect their metabolism materially. Characteristic of this latter group are the glaciers on the slopes of Knife Peak, Katmai and Trident Volcanoes, which are here named the Knife Creek Glaciers (Figs. 2 and 3, p. II7 and 121).

Knife Creek is a shallow, swift, braided stream that flows from the foot of Katmai Volcano westward to the Ukak River and thence north into Iliuk Arm of Naknek Lake. From the base of Katmai Volcano to the Ukak River, a distance of about 12 miles (19 km.), Knife Creek follows a broad, glaciated valley partly filled with pyroclastic debris. Since the 1912 eruption of Katmai Volcano the valley and its slopes have been desolate and almost devoid of vegetation.

Knife Creek carries melt water from the Knife Creek Glaciers, which are here indicated numerically, counterclockwise, around the head of Knife Creek valley from Trident toward Katmai (from left to right in Fig. 2). First and Second Glaciers rise on the slopes of Trident Volcano. Third Glacier heads at the rim of Katmai Caldera, but most of its accumulation zone lies in the saddle south-west of the caldera. The largest of the Knife Creek Glaciers is Fourth, which covers an area of more than 4 square miles (ro $\left.\mathrm{km}^{2}{ }^{2}\right)$ and extends west nearly 4 miles $(6 \mathrm{~km}$.) from ice fields at the caldera rim. Fifth Glacier is the smallest of those on Katmai Volcano, and, unlike

- Publication authorized by the Director, U.S. Geological Survey. 
Third and Fourth, does not originate in the summit ice fields at the edge of the caldera. Other glaciers of the Knife Creek group, on Knife Peak to the north-west, are not included in the present study.

Elevations of the termini of the Knife Creek Glaciers (Fig. 3) in 1953 were estimated as follows : First, $2450 \mathrm{ft}$. (747 m.); Second, $2600 \mathrm{ft}$. (793 m.); Third, $2400 \mathrm{ft}$. (732 m.); Fourth, $2175 \mathrm{ft}$. $(663 \mathrm{~m}$.$) ; Fifth, 2300 \mathrm{ft}$. (701 m.).

Prior to 1912 this area had been little explored. Spurr ${ }^{1}$, had described moraine and valley train topography in the valley of Knife Creek, but he did not mention glaciers on either Katmai or Trident Volcanoes. In $19{ }^{1} 5$, and for several seasons thereafter, the National Geographic Society sponsored investigations in the Katmai area under the leadership of R. F. Griggs. At that time the exposed ends of beheaded glaciers extended as ice cliffs for several miles along the westerly and northerly rims of the Caldera. Where gradients of the glacier surface were relatively steep the ejecta had been dislodged by the development of seracs and crevasses, but in general the blanket of ash and pumice was so little disturbed that even the glacier margins were difficult to recognize ${ }^{2}$. As recently as I95I the Knife Creek Glaciers were still omitted from topographic maps of the Katmai district.

The geography, geology, climatic setting, and volcanic history of the Katmai area have been summarized in recent literature ${ }^{3,4}$.

Present glaciers in the Aleutian Range are small counterparts of the large bodies of ice which in the Pleistocene epoch filled most of the mountain valleys, coalescing as an extensive piedmont glacier on the Bristol Bay lowlands to the west, and as shelf ice in Shelikof Straits to the east $5,6$. The present Knife Creek Glaciers occupy a very small part of the collecting area of the larger Knife Creek tributary glacier, which joined trunk glaciers from adjacent valleys to form ice tongues in the basins of Brooks and Naknek Lakes. Marginal deposits of the Brooks Lake glaciation ${ }^{5}$, believed to be of Wisconsin age, border the lakes on the west. Recessional stillstands and at least one minor readvance have been described in the area of the lake basins.

In valleys not affected by the eruption of Katmai Volcano, remnants of moraines within a few miles of the termini of present-day glaciers give evidence of minor oscillations of glacier margins within recent centuries. In the vicinity of Katmai Volcano, however, deposits which may record these minor fluctuations have been obscured beneath pyroclastic material of the 1912 eruption. Welded tuff and stratified pumice gravel fill the valley of Knife Creek to an average depth of perhaps more than $100 \mathrm{ft}$. $(30 \mathrm{~m}$.), obliterating minor underlying relief features.

Investigations by the writers in 1953 included a detailed study of stratigraphy of pyroclastic deposits near the termini of Fourth and Fifth Glaciers, ablation measurements on Fourth Glacier, establishment of picture points, and observation of glacier morphology. Data were obtained which show that the terminus of Fourth Glacier has been essentially stationary since r912. Changes in the zones of accumulation and ablation which have led to this stagnation are considered below.

\section{GLACIOLOGY}

Of fundamental importance in the study of Fourth Glacier is an analysis of the evidence which has led the authors to conclude that it is in fact static.

The first line of evidence in this connexion is illustrated by Fig. 4, p. 12r. This photograph was taken at the toe of Fourth Glacier and shows thick, flat-lying, well-bedded, and well-sorted pumice deposits lying near to, and directly against, the ice margin. These pumice deposits are in all respects similar to, and appear to be continuous with, surficial pumice deposits throughout the Valley of Ten Thousand Smokes area. The nature of the bedding and sorting of these deposits argues against their genesis as "ice contact" materials from the flanks of an active glacier. The lack of distortion in the deposits precludes advance of the glacier margins since their deposition, and their proximity to the ice front militates against retreat of the ice since their deposition.

The continuity and conformity of these deposits with comparable bedded pumice sections throughout the Katmai area indicate that they belong to the 1912 eruptive sequence. 
A second line of evidence indicating complete stagnation may be observed in the ice fall zone of Fourth Glacier. Seracs and intercrevasse ridges within the ice fall zone are in many places surmounted by perched sections of pumice, in some places as much as several feet thick, precariously balanced above open crevasses. Since these deposits are completely unconsolidated, the slightest movement within the ice fall would quickly topple them over.

There is a complete lack of grinding, rumbling, or other audible evidence of movement often associated with active glaciers either in the terminal zone or the ice fall zone, and the melt water stream fed by the glacier carries less water and shows less diurnal variation in discharge volume than would normally be expected from a stream originating from a glacier of this size.

If Fourth Glacier is in fact static, as its relationship to the 1912 pumice deposits appears to indicate, two basic controls over its regimen must be sought. The first of these controls must be sufficient to have prevented advance of the ice margin since I9I2 and could be expected to have operated primarily in the zone of accumulation. The second control must have been sufficient to have prevented retreat of the ice margin since 1912 and could be expected to have operated primarily in the zone of ablation.

Examination of the zone of accumulation of the Knife Creek Glaciers reveals a significant cause for an abrupt change in regimen. Griggs ${ }^{2}$ published a reconstruction of the pre-eruption Mount Katmai based upon the topography of U.S. Coast and Geodetic Survey Chart 8555 and on the survey of the remaining stub by members of his party. From his reconstruction he computed that approximately i 1,000 million cubic yards $\left(8,400\right.$ million $\left.\mathrm{m}^{3}\right)$ of material had disappeared from the summit zone of Mount Katmai. He described and photographed ice cliffs, the exposed ends of beheaded glaciers stretching for several miles along the caldera rim. These truncated ice fields no longer exist. A conservative estimate of the surface area of the missing summit pyramid, computed from Griggs' reconstruction, which incorporates the best data available, would be of the order of 5 square miles $\left(\mathrm{r}_{3} \mathrm{~km}{ }^{2}\right)$. When it is considered that this lost surface area all lay above $6000 \mathrm{ft}$. $(1830 \mathrm{~m}$.) and that much of it was ice-covered, as is clearly demonstrated by Griggs' photographs of the truncated ice walls on the caldera rim, the effect of this loss of accumulative area on the metabolism of the glaciers can be understood.

\section{Ablation Data}

In view of the severe loss of accumulation area and the effect of secular climatic change, Fourth Glacier might be expected to have undergone extreme downwasting. This would undoubtedly have been the case, except for the marked effect of the blanket of ash and pumice in decreasing ablation losses.

A series of ablation stakes were emplaced on Fourth Glacier on July 8 for study of the insulating effect of the pumice cover. Bamboo poles about $9 \mathrm{ft}$. $\left(2 \cdot 7 \mathrm{~m}\right.$.) long and $\mathrm{I}$ in. $\left(25^{\circ} \mathrm{mm}\right.$.) in diameter were placed in holes bored by hand with a $\mathrm{I}_{\frac{1}{4}}$ in. soil auger. The ablation stakes were rechecked on 3 September to ascertain the extent of seasonal downmelting of the surface. The data, though meager, show clearly how the insulating pumice cover cuts down on ablation losses and preserves the ice tongue.

Two stakes (ra and $\mathrm{rb}$ ) were set up on the relatively level surface of a low, rounded, pumicecovered ice knoll at $2700 \mathrm{ft}$. $(823 \mathrm{~m}$.) above sea-level. The pumice blanket at this elevation is more than $8 \mathrm{ft}$. thick. A second set of stakes ( $2 \mathrm{a}$ and $2 \mathrm{~b}$ ) was placed at about $3800 \mathrm{ft}$. ( 1 I $58 \mathrm{~m}$.) above sealevel, approximately at the level of the base of the ice fall and 200 yards $(94 \mathrm{~m}$.) north of the low saddle between Third and Fourth Glaciers. A fifth stake (3) was set up in the snow field at 5400 $\mathrm{ft}$. ( $1646 \mathrm{~m}$.) above sea-level near the caldera rim. Data on the five ablation stakes are summarized in Table I. 
Table I. Data from Ablation Stakes on Fourth Glacier in 1953 Katmai National Monument

\begin{tabular}{|c|c|c|c|}
\hline $\begin{array}{l}\text { Stake } \\
\text { No. }\end{array}$ & $\begin{array}{l}\text { Altitude above } \\
\text { mean sea-level }\end{array}$ & Emplaced on 8 fuly & Checked on 3 September \\
\hline Ia & $\begin{array}{l}2700 \mathrm{ft} \\
(823 \mathrm{~m} .)\end{array}$ & $\begin{array}{l}\text { In frozen pumice. Frost table ex- } \\
\text { posed to insolation by excavation. }\end{array}$ & $\begin{array}{l}\text { No lowering of surface. Surface level } \\
\text { of frost table depressed } 36 \text { in. } \\
\text { (0.91 m.). }\end{array}$ \\
\hline Ib & $\begin{array}{l}2700 \mathrm{ft} \\
(823 \mathrm{~m} .)\end{array}$ & $\begin{array}{l}\text { Through thawed surface zone into } \\
\text { frozen pumice. Frost table undis- } \\
\text { turbed by excavation. }\end{array}$ & $\begin{array}{l}\text { No lowering of surface. Surface } \\
\text { level of frost table stationary. }\end{array}$ \\
\hline $2 a$ & $\begin{array}{l}3800 \mathrm{ft} . \\
(1158 \mathrm{~m} .)\end{array}$ & $\begin{array}{l}\text { In seasonal snow with about } \mathrm{I} \text { in. } \\
\text { of ash cover from Trident Vol- } \\
\text { cano. No pumice mantle. }\end{array}$ & $\begin{array}{l}\text { Stake dropped into crevasse and } \\
\text { snow completely melted. }\end{array}$ \\
\hline $2 \mathrm{~b}$ & $\begin{array}{l}3800 \mathrm{ft} . \\
(\mathrm{I} 158 \mathrm{~m} .)\end{array}$ & $\begin{array}{l}\text { In exposed ice ridge with } 2 \text { to } 3 \text { in. } \\
\text { of pumice cover. }\end{array}$ & $\begin{array}{l}\text { Downmelting totaled } 34 \text { in. }(86 \cdot 3 \\
\mathrm{cm} \text {.) or } 0.6 \text { in. }\left(\mathrm{r}^{\prime} 5 \mathrm{~cm} \text {.) per day. }\right.\end{array}$ \\
\hline 3 & $\begin{array}{l}5400 \mathrm{ft} . \\
(1646 \mathrm{~m} .)\end{array}$ & $\begin{array}{l}\text { In seasonal snow on ice field at } \\
\text { caldera rim. }\end{array}$ & $\begin{array}{l}\text { Downmelting exceeded } 1 \cdot 2 \text { in. } \\
(3 \cdot 0 \mathrm{~cm} \text {.) per day. Stake had } \\
\text { melted out and fallen. }\end{array}$ \\
\hline
\end{tabular}

These observations indicate that:

I. Ablation of snow at $5400 \mathrm{ft}$. in the accumulation area of Fourth Glacier, even through a $I_{4} \frac{1}{4}$-inch-thick $(3 \cdot 2 \mathrm{~cm}$.) layer of fine black ash, exceeded $\mathrm{I} \cdot 2$ in. per day by an unknown amount during July and August.

2. Ice with only 2 to 3 in. of pumice cover, in an exposed location at $3800 \mathrm{ft}$., melted $0.6 \mathrm{in}$. per day during the same period.

3. Seasonal thaw probably penetrates less than $4 \mathrm{ft}$. $(\mathrm{I} \cdot 2 \mathrm{~m}$.) into the frozen pumice which blankets the lower portions of the Knife Creek Glaciers. In other words, permafrost has aggraded to within $4 \mathrm{ft}$. of the surface of this blanket, and a cover of more than $4 \mathrm{ft}$. of pumice assures minimum ablation even in the zone of wastage.

Whereas thin debris cover facilitates melting of snow or ice by increasing heat absorption at the surface, thicker cover, because of its low heat conduction, insulates and retards ablation. The critical thickness of ash cover necessary for the insulating effect to become dominant over the effect of increased absorption is a function of such physical properties as the color, texture, and compactness of the ash. Observations near the National Park Service Katmai Project's base camp at Knife Creek illustrate the effectiveness of volcanic ash in retarding ablation. Measurements on comparable areas of clean snow and of snow covered by less than an inch of ash from Trident Volcano showed the rate of ablation of the clean snow to be 5 times that of the insulated snow. In other words, a critical thickness of somewhat less than $\mathrm{I}$ in. of loosely compacted ash from Trident Volcano is adequate to significantly retard melting of subjacent material.

Thus it would appear that the second control required for the static condition of the Knife Creek Glaciers is fulfilled by the insulating properties of the thick pumice deposits within the zone of ablation.

\section{COMPARISON OF PHOTOGRAPHS}

A panorama of the Knife Creek Glaciers (Fig. 5, p. I2 I) was photographed July 6, I953, from the lower, more easterly of two crests of Broken Mountain (see Fig. 3). The station lies a few hundred feet west of the point at which a now very mildly active fumarolic fissure crosses the ridge of Broken Mountain. The panorama affords a fairly unobstructed view of the Knife Creek Glaciers, which it is hoped will be duplicated at intervals in future years to record changes in the thickness and extent of the glaciers. A complementary view of Fourth Glacier from the north-north-west on the lower slopes of Knife Peak, taken under adverse weather conditions, was rain damaged. Although not reproduced here, it is available through the U.S. Geological Survey, Photo Library, in Denver, Colorado, for future comparison. 
A photograph by C. N. Fenner ${ }^{7}$, a member of one of the National Geographic Society expeditions, shows Third Glacier from the west. No early photograph of Fourth Glacier is known. The Knife Creek Glaciers have recently been photographed from the air, by the U.S. Air Force in I946 (Fig. 3) and by the U.S. Navy in I95 I, on mapping quality vertical photography. Comparison of these photographs and the panorama taken in 1953 shows no significant change in the margin of Fourth Glacier within the past few years.

\section{CONCLUSION}

On the basis of the undisturbed condition of pyroclastic debris adjacent to the terminus of Fourth Glacier, the morphology of the glacier, ablation studies at several elevations, and a comparison of the few available photographs it is concluded that:

I. The terminus of Fourth Glacier has been essentially stationary over the past 40 years.

2. Ablation losses from the body of Fourth Glacier have been reduced to a minimum by the thick, insulating mantle of pumice and ash. So effective is this insulation that parts of the pumice mantle are now permanently frozen to within a few feet of the surface.

3. Thinning of the upper reaches of the glacier has resulted from loss of a major part of the accumulation area, slight movement downslope, and perhaps secular climatic amelioration.

This description of the previously unmapped Knife Creek Glaciers and report on the regimen of Fourth Glacier are based on reconnaissance work in the area. It is believed that other glaciers in the vicinity of Katmai Volcano will repay future study and may demonstrate quite dissimilar response to changes brought about by the volcanic eruption of I 912 .

MS. received II May 1956

\section{RE F E RE N CES}

I. Spurr, J. E. A reconnaissance in southwestern Alaska in 1898 . U. S. Geological Survey. 2oth Annual Report, [for the year] $1898-99$, Pt. 8, r 900 , p. $31-264$.

2. Griggs, R. F. The Valley of Ten Thousand Smokes. Washington, National Geographic Society, 1922.

3. Muller, E. H., and Coulter, H. W. Incipient glacier development within Katmai caldera, Alaska. Fournal of Glaciology, Vol. 3, No. 21, 1957, p. $13-17$.

4. Curtis, G. H. Importance of Novarupta during the eruption of Mt. Katmai, Alaska, in I9r2. Bulletin of the Geological Society of America, Vol. 66, No. 12, 1955, p. 1547.

5. Muller, E. H. Northern Alaska Peninsula and eastern Kilbuck Mountains, Alaska. (In Péwé, T. L., and others. Multiple glaciation in Alaska. U. S. Geological Survey. Circular, No. 289, 1953, p. 2-3.)

6. Karlstrom, T. N. V. Upper Cook Inlet region, Alaska. (In Péwé, T. L., and others. Multiple glaciation in Alaska. U. S. Geological Survey. Circular, No. 289, 1953, p. 3-5.)

7. Fenner, C. N. The Katmai magmatic province. fournal of Geology, Vol. 34, 1926, p. 675-771.

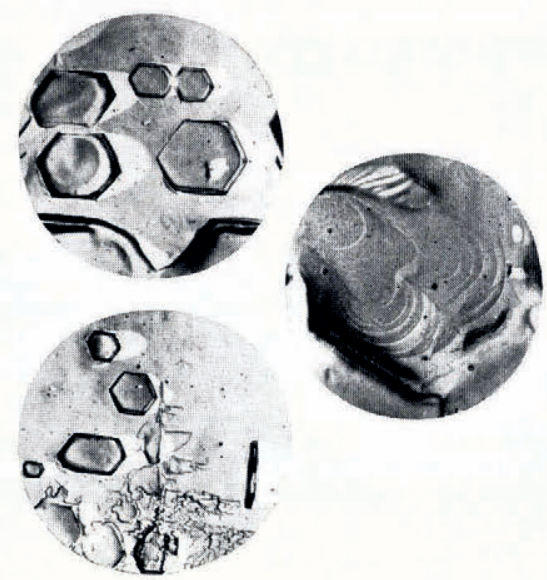

Figs. 2 and 3 (left). Microphotographs of shadowed replicas of etched ice crystals. The crystal in Fig. 2 and the grain on the left of Fig. 3 have faces perpendicular to the c-axis. The right hand grain in Fig. 3 has a face parallel to to the c-axis. Magnification $\times I_{3}$

Fig. 4 (right). Replica of the stepped structure observed at the base of a hexagonal etch pit. Magnification $\times 35$ 